\title{
Letter from the Editor-in-Chief
}

\section{寄稿ノス、メ}

\section{Benefits of Contributing to the JMSSJ}

\author{
吉野健一1,2 \\ Ken-ichi Yoshino ${ }^{1,2}$ \\ 1 神戸大学・自然科学系先端融合研究環・バイオシグナル研究センター Biosignal Research Center, \\ Organization of Advanced Science and Technology, Kobe University, Kobe, JAPAN \\ 2 編集委員長 Editor-in-chief
}

本誌「質量分析 Journal of the Mass Spectrometry Society of Japan (JMSSJ)」の刊行は, 日本質量分析学会 the Mass Spectrometry Society of Japan (MSSJ) の定款第 3 条に定められた主たる事業の一つです.

学会誌の刊行に並ぶその他の主たる事業としては, 質量分析総合討論会の開催が挙げられます.しかしながら, 現行の規 定では, MSSJ の会員資格は, 質量分析総合討論会において研究発表を行うためや, 質量分析総合討論会に参加するための 必要条件ではありません，共同演者にあ会員資格を要求する学会があるなか，MSSJ はとても懐の広い寬大な学会なので す.

MSSJ の会員であることの特典として, 正会員や学生会員は質量分析総合討論会の参加登録費の優遇を受けることはで きますが，会員資格があるからといって参加登録費が免除されるわけではありません。

MSSJ の会員であることによって得ることのできる特典のなかで最あ主要なことは, 実はこの JMSSJ が定期的にお手 元に届き, 読むことができることなのです.MSSJ の会員資格を有する方であれば, 特に追加料金を払う必要なく, いち早 く本誌の読者となることができるわけです，MSSJの会員資格をむっていない方は，冊子版よりも若干公開が遅いオンラ イン版だけが情報の入手手段となります。

非会員の誰よりも早くこの JMSSJ を手にとって読むことができる。これが MSSJ 会員であることの最大のメリットな のです.

JMSSJ は, 主としてMSSJ 会員からの寄稿によって成り立っています。そして寄稿者は次のような恩恵を享受すること ができます。

\section{1.「学会賞」を受賞できます}

受賞者選考細則に記された日本質量分析学会「学会賞」MSSJ Award for Distinguished Contribution in MS 受賞候補 者の資格として,「受賞の対象となる原著論文を 5 編以上本学会誌に報告しているすのとする」と記されています.JMSSJ に原著論文が 5 編以上掲載されていることが「学会賞」受賞の必要条件です。

\section{2.「奨励賞」を受賞できます}

受賞者選考細則に記された日本質量分析学会「奨励賞」MSSJ Research Award 受賞候補者の資格として, 「受賞の対象 となる原著論文を 1 編以上本学会誌に報告しているすのとする」と記されています. JMSSJ に原著論文が 1 編以上掲載さ れていることが「奨励賞」受賞の必要条件です。

若手の皆さん，今のうちに本誌に原著論文を投稿し，奨励賞受賞を目指してください，せっかく候補に上がっても JMSSJ にあなたの原著論文が掲載されていなかった場合，誠に残念ながら，推薦されることはありません。

\section{3.「論文賞」を受賞できます}

日本質量分析学会「論文賞」JMSSJ Award for Excellent Paper はJMSSJに掲載された「原著論文」すすおわち「一般 論文」，「ノート」，「技術報告」の著者から選考され，授与されます．

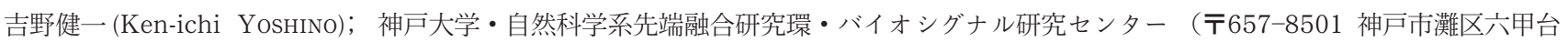
町 1-1); e-mail: kyoshino@kobe-u.ac.jp 
来年度 2008 年度の論文賞は 2006 年発行の Vol. 54 に掲載された原著論文の著者から選考されます. 本年 2007 年中に 揭載された原著論文の著者は 2009 年度の論文賞受賞の候補者となります。

会員の皆様，論文賞受賞を目指して，JMSSJ に質の高い原著論文を打寄せください．

\section{4.「会誌賞」を受賞できます}

日本質量分析学会「会誌賞 JMSSJ Award for Excellent Article」は, JMSSJ に掲載された総説論文，すなわち「総説」， 「総合論文」,「解説」と「Letter to the Editor」の著者から選考され，授与されます。

来年度 2008 年度の会誌賞は 2006 年発行の Vol. 54 に揭載された総説論文と Letter to the Editor の著者から選考され ます．本年 2007 年中に掲載された総説論文と Letter to the Editor の著者は 2009 年度の会誌賞受賞の候補者となりま す.

会員の皆様, 会誌賞受賞を目指して, JMSSJ に質の高い総説論文（「総説」,「総合論文」「「解説」）および Letter to the Editor をお寄せください.

\section{5. 英文ネイティブチェックサービスを無料で受けることができます}

採択された論文の英文ネイティブチェック（英文校閲）の費用は編集委員会が負担いたします（ただしこのサービスは 編集委員会の財政状況の変化に伴い予告なしに打ち切られることがあります)

\section{6. 別刷 25 部を無料で進呈いたします}

従来, 本誌に原著論文や総説論文が掲載された著者は別刷 50 部を購入する義務か課せられていました。しかしながら, 2005 年 3 月末をむってこの制度は撤廃され, 代わりに 25 部を無料で進呈しています。（このサービスは原著論文と総説 論文が対象であり，原則として Letter to the Editor の著者へのサービスは行っていません，ただし，学術的に重要であ り, 原著論文や総説論文と同様に, 公表後, 著者が別刷を必要とする可能性が高いと編集長が判断した場合には Letter to the Editor の別刷 25 部無料進呈を行います)

\section{7. 投稿料, 掲載料は不要}

日本質量分析学会編集委員会は, JMSSJ に採択が決定された原稿の掲載料 (投稿料) 等, 編集, 印刷, 出版に必要な経 費を著者に請求することはありません。ただし, カラー印刷等, 本誌の通常の方法とは異なる印刷方法を著者が希望された 場合はこの限りではありません。

\section{8. 迅速な査読}

一次審査の結果は, 原則として受付日から 21 日以内に抢知らせいたします.さまざまな理由で審査結果, 特に採択通知 が早期に必要とされる場合があります. 科学的な錯誤がなく, 揭載に值する論文の審査はできるだけ早く行い, 一日も早く 查読結果を扮知らせすることを心がけたいと考えています。

改定前の投稿規程の下では, 投稿や査読業務に抢いて, 紙媒体の原稿のやりとりを行う必要がありました. 2005 年 5 月 の投稿規程改定以降は，電子メールを利用して電子ファイルを媒体とした原稿のやりとりが行われていますので，最速の 場合，投稿日が採択日となることも可能です ${ }^{11}$.

\section{1,300 名の MSSJ 会員の目にとまります}

現在, 日本質量分析学会の会員数はおよそ 1,300 名です.この会誌は, 偶数月の初め, すべての会員のお手元に定期的に 届けられています。

\section{0. 世界中の MS 関係者の目にとまります}

JMSSJ に掲載された論文等は, 本会のウェブサイト [URL:〈http://www.mssj.jp/index-jp.html〉] 上の「オンライン質 量分析」において公開されています。

また，独立行政法人日本科学技術振興機構が運営している科学技術情報発信・流通総合システム the Japan Science and Technology Information Aggregator, Electronic (J-STAGE) [URL:〈http://info.jstage.jst.go.jp/info/〉]において あ公開されています。

残念ながら，質量分析に携わっている人の中にはまだMSSJ の会員になられていない方む扔られます。さまざまな理由

略語, JMSSJ, Journal of the Mass Spectrometry Society of Japan (日本質量分析学会誌); J-STAGE, the Japan Science and Technology Information Aggregator, Electronic（科学技術情報発信・流通総合システム); MS, mass spectrometry（質量分析）； MSSJ, the Mass Spectrometry Society of Japan (日本質量分析学会); URL, uniform resource locator 


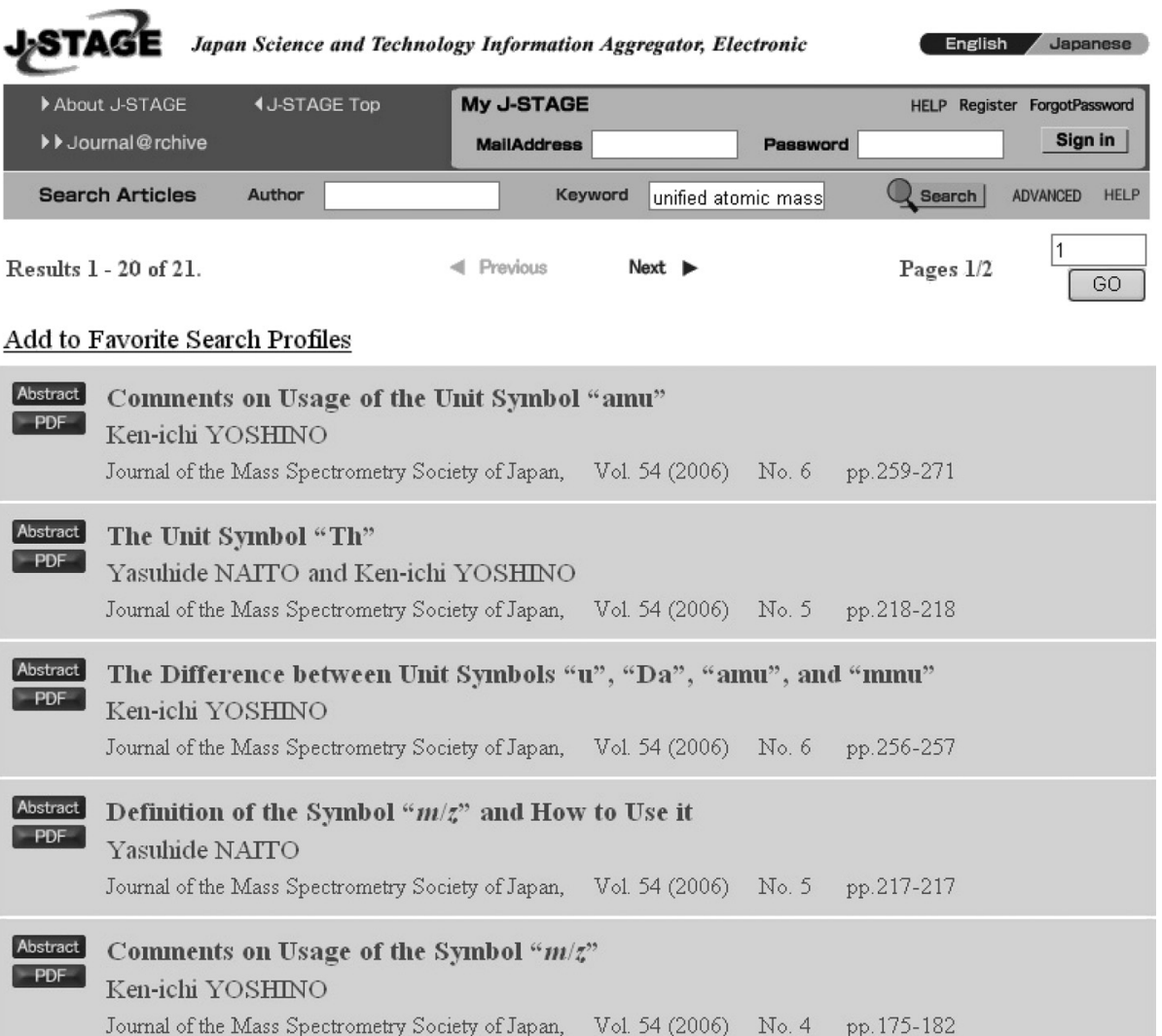

Fig. 1.J-STAGE 検索サイト，検索結果の一例.「unified atomic mass unit」をキーワードとして検索を行った. 英語版検索サイトの URL:〈http://www.jstage.jst.go.jp/browse/〉

日本語版検索サイトの URL:〈http://www.jstage.jst.go.jp/browse/-char/ja〉

で, MSSJ の入会手続きがお済みではなく, JMSSJを手にとって読むことができない方にも，オンライン質量分析やJSTAGE 上でJMSSJ に掲載された論文等を読んでいただくことは可能です.

また, JMSSJ の存在をご存じでない方でも, J-STAGE の検索サイトからキーワード検索等で JMSSJ に掲載された論文 等にアクセスすることが可能です (Fig. 1).J-STAGE 上で公開されている論文は, ChemPort 等を経由し, 海外のさまざ まな電子ジャーナルサイト上の論文と相互リンクされています.

JMSSJ は全世界に開かれているジャーナルです.

\section{1. 総説論文や Letter to the Editor の活用}

原著論文とは, 新規に得られた科学的な知見をまとめ, その知見に基づき筋道を立てて意見を表明し, 議論を行う学術的 な著作物です。

しかしながら, 学術的な著作物は原著論文だけではありません, 総説, 総合論文, 解説, すべて学術的な著作物であり論 文です. 学術論文として重要なことは, 科学的な知見と体系に基づき, 新規性の高い研究者自身のアイディアを表明し, 学 術的な議論を行うことです. 学術論文に必要なことは, 必ずしも新規に得られた実験結果ではなく, 研究者自身が実験結果 から導き出した新規性の高いアイディアです。実験科学の原著論文に扔いて新規な実験結果を得ることは, 必要条件です が，十分条件ではありません。

学術的に新規な知見, アイディアを表明し議論する場は何む原著論文に限ったことではありません. 総説, 総合論文, 解 説を媒体として行うことも可能ですし，アイディアの内容によっては，原著論文よりもこれらの著作物のほうが適切な場 合ああります。

研究者として, 科学者として, 世に問いたいこと, 表明したいアイディア, ご意見, ご提案, 皆様の頭の中から数多く湧 き出ていると思います。ぜひそのような学術的な提言を, 皆様の胸のうちにとどめておくことなく, JMSSJ の総説, 総合 論文, 解説を活用し, 表明し, 世界に向けてどんどんアピールしてください. 国外のジャーナルではさまざまな理由で受け 入れてもらえない㧈それもあります。しかしながら, JMSSJ は, 懐の広い MSSJ の学会誌ですから, とても懐の広い ジャーナルです. 記述内容に科学的な錯誤がない限り, 掲載には何の障害あありません. きっと皆様の斬新なアイディア, ご意見をアピールする場, 皆様のユニークなひらめきを公表する場として有用であると確信しています. 
総説や総合論文の執筆は少々ハードルが高いかもしれません，しかし，JMSSJには Letter to the Editor というカテゴ リーがあります.このカテゴリーは自由度の高い枠で, 採否の決定は編集長が行っています. 第三者の審査・査読を受ける ことなく時の編集長の查読によって採否が決定されます。科学的な錯誤がない限り，いろいろな形の著作物を受け入れる ことが可能です. たいへんハードルの低いカテゴリーですので, この Letter to the Editor 有効に活用し, 皆様の学術的 なご意見，ご提案，ユニークなアイディアを全世界にアピールする場として，ぜひ JMSSJ をご活用ください.

ペプチド主鎖の結合が開裂することによって生成したフラグメントイオンは, a-ion, b-ion, c-ion, x-ion, y-ion, z-ion と 呼ばれています，現在，世界中で利用されているこの命名法を提案した最初の文献は, 1984 年 P. Roepstorff \& J. Fohlman が Biomedical Mass Spectrometry 誌に発表した Letter to the Editor ${ }^{2)}$ です。歴代の MS 関連の文献の中で, この Letter to the Editor の引用回数が上位を占めていることは想像に難くありません.

皆様, ぜひとも, ペプチド由来のフラグメントイオンの命名法を提案した, この P. Roepstorff \& J. Fohlman の Letter to the Editor を超えるような歴史を創るユニークな Letter to the Editor や原著論文, 総説, 総合論文, 解説を JMSSJ お寄せください.

\section{文献}

1) 吉野健一, J. Mass Spectrom. Soc. Jpn., 53, 239 (2005).

2) P. Roepstorff and J. Fohlman, Biomed. Mass Spectrom., 11, 601 (1984).

【挑断り】本稿に記されている日本質量分析学会の各種規定や, 日本質量分析学会誌「Journal of the Mass Spectrometry Society of Japan」に寄稿することによって得ることができるサービスは, 執筆時（2007年 6 月 1 日）に扔いて有効な事項です。これらの規定や サービスは予告なく変更されることがあります. 